\title{
The changing fortunes of intermediary agencies: Reconfiguring higher education policy in Norway and Australia
}

Jens Jungblut \& Peter Woelert

Published as:

Jungblut, J., \& Woelert, P. (2018). The Changing Fortunes of Intermediary Agencies: Reconfiguring Higher Education Policy in Norway and Australia. In: P. Maassen, M. Nerland, \& L. Yates (Eds.), Reconfiguring Knowledge in Higher Education (pp. 25-48). Cham: Springer International Publishing

\section{Introduction}

Higher education policy has attained increasing salience and relevance among contemporary states and societies. There are at least two major factors contributing to this development. First, the continuous massification of higher education, implying that an increasing percentage of the population is participating in higher education (Andres \& Pechar, 2013), has led to increased public or private investments in the sector (Altbach, Reisberg, \& Rumbley, 2009). Second, in contemporary, knowledgeintensive societies, higher education has become a policy area that is believed to be fundamentally linked to capacity-building in other policy areas, such as national innovation and employment (Gornitzka \& Maassen, 2014).

In this context, the rising importance of higher education policy and the move towards knowledge economies could be seen as part of a set of overarching global trends of reform that affect higher education policies and systems and which are often described as 'global scripts' (Meyer, Ramirez, Frank, \& Schofer, 2007). One of these trends is what has been referred to as 'agentification' (Capano \& Turri, 2016; also Verhoest, Thiel, Bouckaert, \& Lægreid, 2012; Christensen \& Lægreid, 2006; Pollitt, Talbot, Caulfield, \& Smullen, 2004). In the public policy literature, agentification refers to the process of using agencies for the purposes of developing and implementing domain-specific policies as well as the associated governance tasks. Such agencies are commonly understood to operate 'at arm's length' from government (see Pollitt \& Talbot, 2004), thus possessing some (albeit constrained) autonomy over policy processes (see Verhoest, Peters, Bouckaert, \& Verschuere, 2004).

The trend toward agentification is commonly considered to be an essential part of governments' endeavoring to decentralize processes of steering in order to create ostensibly more responsive, flexible and informed forms of public governance (see Pollitt, 2005). In particular, agentification is commonly associated with the spreading of New Public Management (NPM) reforms and 'steering at a distance' modes of governance (see Verhoest et al., 2012; Pollitt, et al., 2004). In the specific policy domain of higher education, such governance modes are often thought to be facilitated by virtue of agencies effectively mediating between government (as the policy 'principal') and the various higher education organizations - hence such agencies are also referred to as 'intermediary' bodies (see de Boer, 1992; Meek, 2002). 
Both NPM and agentification can be seen as part of global scripts exerting rather homogenous pressures on national higher education systems, leading to an increasing, homogenizing policy influence on changes in the funding, governance and organization of higher education institutions. However, various authors have stressed that ostensibly global scripts, such as NPM, do not act uniformly on national higher education systems but are translated into national reform agendas and policy initiatives that reflect historically entrenched national as well as institutional norms and structures (see e.g. Bleiklie \& Michelsen, 2012; Gornitzka \& Maassen, 2014; Krücken, 2003). These, it has been argued, act as filters that tend to adapt global reform trends to what is perceived as appropriate in a given national or institutional policy context, and which imply differently accentuated forms of political control and steering. It is only recently that this process has been examined with regard to the specific role agencies play in national higher education policy processes (see Capano \& Turri, 2016).

Building inter alia upon typologies of agencies put forward in this context, this chapter examines in detail the changing role and fortunes of agencies in the domain of higher education policy of two countries - Norway and Australia. In doing so, we move beyond the few existing comparative examinations of agentification in the domain of higher education policy (e.g., Capano \& Turri, 2016) in three respects. First, our examination focuses on two countries only, thus allowing for a more detailed and in-depth analysis of the national cases selected. Second, it pays greater attention to how in each country agencies' role is embedded within a wider institutional matrix for coordinating policy processes, thus getting a better grip on the highly complex ecology of processes and determinants shaping national higher education policies (Gornitzka, Maassen, Olsen, \& Stensaker, 2007). Third, we track the changing role and fortunes of relevant agencies in each country over an extended period of time - roughly the past thirty years. Doing so enables us to give the constitution of agentification its due as a process, facilitating better understanding of how the roles and fortunes of agencies are contingent to change over time.

The two countries - Norway and Australia - are selected since they share some major policy imperatives with regard to their higher education systems - mainly to increase accountability and efficiency, - yet they also exhibit key differences in their approaches to agentification, particular as concerns the stability of the institutional configuration of agencies responsible for policy processes. Also of interest is that Australia can be described as being in the vanguard internationally of NPMreforms (Lewis, 2015; Marginson \& Considine, 2000) that entail some embracing of marketization forces, while seemingly Norway has taken a more moderate route in adapting NPM reforms due to its traditionally strong state and the Nordic welfare model (Bleiklie, 2009).

Our discussion will proceed as follows. The next section will introduce the conceptual framework for the analysis of agentification in the domain of higher education policy, also considering in this context the relation between agentification strategies and alternative strategies for coordinating higher education policy processes (see Braun 2008). Subsequently, the empirical background of the two countries as well as the data and methods for the analysis are discussed. Next the institutional reconfiguration of agencies and other relevant policy actors are analyzed for each country over a period covering roughly the last 30 years. In the final section a succinct comparison of and reflection on the two cases is provided, also including identification of specific avenues for further research. 


\section{Intermediary agencies and the coordination of higher education policy}

While the issue of agentification has received considerable attention in the public policy literature over the last decades (see Verhoest, et al., 2012; Pollitt \& Talbot, 2004,), it remains an underrepresented topic in the more recent higher education policy literature. Within the latter literature, there are only few publications explicitly devoted to this issue (see Capano \& Turri, 2016), although it is of note that there is a slightly older and thematically related body of literature on agencies operating as 'intermediary' or 'buffering' organizations (e.g., de Boer, 1992; Meek, 2002). Synthesizing and building upon these relevant literatures, in this section we conceptualize a framework for analyzing the role of agencies in higher education policy processes. We begin by examining the mediating and 'buffering' role agencies are supposed to play in higher education policy processes, considering in this context the potential advantages and problems that are associated with this role. Subsequently we discuss Capano and Turri's recent typology of agencies and their higher education policy role (2016), which will guide the empirical examinations of the two national cases. Finally, and going beyond this typology, we briefly discuss additional institutional options for higher education policy coordination and elaborate upon how these may enable or constrain agentification. In doing so we acknowledge that national higher education policy most of the time is administered by a network of multiple ministries and governmental agencies (see Gornitzka, et al., 2007) shaping and constraining the policy capacity of each individual agency.

Within national higher education systems, agencies are commonly expected to fulfill an intermediary or buffering function between government and the various higher education institutions (see de Boer, 1992; Meek, 2002). This obviously implies that an agency needs to maintain and balance two key relationships, one with government and one with the higher education institutions (de Boer, 1992, 36). This balancing is essential for an agency's retaining of legitimacy with both sides and ultimately its own effective functioning as an intermediary - if it is too closely associated with government it will be viewed as a direct extension of the former by the higher education sector, while a too close association with the sector will mean government losing trust in the agency and its policy capacities (see below for more detail).

Using intermediary agencies for higher education policy coordination and processes has a range of potential advantages for governments (de Boer, 1992, 36-37). First, the use of such agencies reduces the number of organizations that a government has to directly engage with on a regular basis to one. This makes communications and negotiations between the higher education sector and government more structured and effective and, arguably, less cost-intensive. Second, intermediary agencies are uniquely positioned to gather and analyze relevant information about the higher education sector, presupposing they have sufficient capacity in terms of staffing and budgets. Third, such agencies may handle conflicts of interest arising between various higher education institutions more effectively than government. Finally, intermediary agencies can be useful agents for implementing policies as they potentially have some authority and legitimacy among higher education institutions.

However, there also potential problems with agentification that have to be considered seriously by governments. First and most fundamentally, ceding policy functions to agencies may mean a loss of control of governments over the (governance of the) higher education sector. As agencies typically operate at some distance from government and there is only a limited amount of tools government can use to steer these agencies, there is little potential for direct hierarchical control of the sector. Adding to this, having an agency positioned in between government and the higher education sector 
also means that governments cannot as easily resort to the "divide and rule" tactic when engaging with higher education institutions (de Boer, 1992, 36). Second, since agencies have considerable control over relevant information, they may choose to be selective in what they pass on to government, in line with their own, strategic agendas. Third, such agendas may be partial to the particular interests of the higher education sector if intermediary agencies develop and maintain too close links to their clientele. Fourth and related to this, there also is a risk of an agency being 'captured' by particularly powerful clients exerting an influence on agency-level policy-making so that sector-wide policies suit their own particular needs and demands (Moran, 2003, chapter 6).

Intermediary agencies can have specific policy functions ranging from direct involvement in policy making, to providing advice that influences the development of policy, to implementing governmental policy. The degree to which agencies can creatively shape policy processes is mainly dependent upon what has been referred to as 'policy autonomy' (Verhoest, et al., 2004). Such autonomy refers to the discretion agencies have over choosing specific policy instruments, goals and objectives (Capano \& Turri, 2016, 3). The policy autonomy of agencies is impacted upon by two conditions. First, there are the legal arrangements that formally define the power and discretion an agency has over conducting its affairs. Second, there is the wider ecology of governance processes (and including informal processes) determining how such formal powers can be realized in practice (Verhoest, et al., 2004).

With specific regard to the policy domain of higher education, Capano and Turri contend $(2016,3)$ that an agency's actual policy powers are impacted upon not only by government's capacity to directly control agencies but also by its capacity, and, one may add, political ambition, "to coherently steer" the entire higher education system. The lower the government's steering capacity and ambition, the higher tends to be the policy autonomy of the concerned agencies. Considering both the formal and actual dimensions of policy autonomy, Capano and Turri (2016, 3-4) then distinguish four ideal types of agencies tasked with higher education policy functions.

First, there is what they call the "dominant agency". This sort of agency has not only considerable policy powers legally, but can also practically exercise these powers to their fullest extent due to a low steering role of government. Such an agency usually occupies the role of central policy actor in a national system of higher education. Second, there is the "additional agency" also enjoying considerable powers formally, but where such powers are in practice severely restricted, either because the government continues to directly intervene in and dominate policy agendas and affairs, or because the agency is lacking the resources and competencies to fulfil its formally allocated role. Third, there is the "administrative agency" having limited powers formally, but where the government nevertheless does not assume a dominant steering role. While the latter condition could theoretically provide scope for the agency to assume a stronger policy role, this tends to be difficult practically as the agency lacks legitimacy due to its restricted formal powers. Finally, there is the "instrumental" agency, which is the weakest type of agency among the types of agencies delineated. The instrumental agency typically is "completely controlled by its principal", that is, government, and tends to be perceived as a subordinate branch of government by the higher education institutions (Capano \& Turri, $2016,4)$. Instrumental agencies are usually charged with the technical and administrative tasks of policy implementation rather than broader and strategic policy functions, and are often bypassed both by governments and higher education institutions when it comes to political negotiations about crucial matters, such as funding. Owing to all this, instrumental agencies are incapable of effectively fulfilling any proper intermediary or buffering function. 
While Capano and Turri rightly see the autonomy of agencies being shaped not only by legal frameworks but also by the wider organization and coherence of governance processes, they have relatively little to say about institutional options for higher education policy coordination other than agentification - and about how these and the associated policy actors may effectively enable or constrain agencies' power and autonomy. This exclusion is limiting also in that agentification in realworld institutional contexts seldom excludes the manifestation and pursuit of alternative institutional options for policy coordination. Drawing on the discussion of Braun (2008) and considering the constitution of the policy autonomy of agencies there are two of such options that are of particular note.

The first option focuses on combining different policy-making bodies in the same policy area (or across related areas) into one larger structure. The most visible form of this is the so called 'superministry' (Braun, 2008). The superministry approach aims to resolve coordination challenges through uniting and integrating core higher education policy portfolios and functions within one ministry with major policy powers. This Ministry is under the direct leadership of one minister who in principle has the authority to develop encompassing strategies and assure compliance of the civil servants. This, in theory at least, should increase efficiency in policy processes as well as increasing coordination between, for example, higher education and research policies. In a similar vein, this approach can also be used with regard to government agencies. In this case several agencies that are active in the same sector would be combined into one 'superagency' that fulfills all previously dispersed functions, while providing an overarching organisational umbrella.

This idealized perception has to address at least three opposing arguments (Braun, 2008). First, within a newly created 'superministry' or agency, older administrative units with their differing organizational cultures may still persist as subunits. Second, if the ministry or agency is very large and heterogeneous in its composition it may be difficult to effectively apply top-down commands, not to mention that the use of hierarchy may not be easily applicable or have unintended effects in a policy area as complex as higher education. Third, even if ministers or heads of agencies would be able to develop an encompassing policy strategy the administrative units opposed to this strategy would still be able to resist, for example, through acts of 'window-dressing' (see Meyer \& Rowan, 1977).

The second option is the use of strategic intelligence (Braun, 2008). This option relies, for example, on the use of external advisory bodies or consultancies that can provide expert knowledge to detect flaws in existing policy arrangements as well as to offer alternatives. The most important function of expert knowledge in this context is the rationalization of political debates, as this has the potential to reduce the influence of distributive in favor of problem-solving arguments. In practical terms, use of such external bodies has the disadvantage that these may lack in-depth understanding of the higher education sector and of the complex effects specific policy options may have on the ground. One may add here also the problem that the use of expert-knowledge as well as the gathering and analysis of objective data supposedly guiding policy development and implementation is often biased and politicized from the very start, thus potentially resulting in fabricating 'policy-based evidence' rather than in practicing 'evidence-based policy' (see Sanderson 2011). This may be particular the case if the government hires external consultancies and where the resulting pecuniary interests may prohibit such consultancies from providing 'objective' advice.

Pursuit of either of these institutional options typically has direct implications for the policy autonomy of agencies as well as for their capacity to fulfill an intermediary or buffering role. The creation of a 
'superministry', for example, usually directly implies a significant restriction of the policy autonomy of agencies and also tends to weaken their capacity to genuinely act as a buffer between government and the higher education sector. Similarly, the use of strategic intelligence can weaken the policy autonomy and standing of agencies, if government opts to bypass them and seeks expert advice from external parties instead. This said, governments may also opt to build up the expert knowledge capacities of their agencies rather than using external parties, or at least charge agencies with the task of engaging with external advisory bodies. In this instance, the use of strategic intelligence may strengthen rather than weaken the policy capacity and standing of agencies.

\section{Research design and the empirical context}

As it is the aim of this chapter to analyze the changing role of agencies in the domain of higher education policy in Norway and Australia, our analytical focus is on the question how in each country the agencies' role is embedded within a wider institutional matrix for coordinating policy processes. Furthermore, we track the changing role and fortunes of relevant agencies in each country over an extended period of time of roughly thirty years. Therefore, we focus not only on the status quo of agentification, but also on the process of constitution of agentification and the matching developments in the institutional environment. The research design that we chose for this could best be described as a comparative historical case study (Gerring, 2007), since we not only cover spatial, but also temporal variation in our data. Our study can therefore also be situated within the growing group of Comparative-Historical Analyses with its focus on configurations, context, institutional complementarities and temporal structure (Thelen \& Mahoney, 2015).

The data basis for the analysis consists of, among other things, the web sites of the respective ministries and agencies, policy documents as well as academic publications. While presenting a general overview over the shifts in higher education policy-making structures in the two countries, we will use the typology by Capano and Turri (2016) to assess the development of key government agencies. In addition, we will use the coordination strategies proposed by Braun (2008) to categorize further developments in the higher education sector.

As already indicated in the introduction, both Norway and Australia share some major reform imperatives with regard to their higher education systems, yet they also are situated on different ends of the reform spectrum. Australia has been in the vanguard of NPM reforms (Lewis, 2015) resulting in some early marketization tendencies, and Norway has often being considered as a state-centric laggard with a strong tradition of generous public welfare principles (e.g. Bleiklie, 2009). Thus, comparing the two countries not only provides an insight into their ways of coordinating higher education policies, but also sheds light on the ways in which specific national filters differently shape and refract global higher education policy reform 'scripts' (Gornitzka \& Maassen, 2014).

\section{The empirical cases compared: Higher education in Norway and Australia}

As a background for the following analysis it is necessary to first give a brief overview of the higher education sectors in the two countries involved. 
Norway has an in essence public higher education system with different types of higher education institutions, that is, research universities, professional higher education institutions (referred to as university colleges), and specialized universities (referred to as scientific colleges). The somewhat diversified structure of today's higher education system is the result of several reforms that started already in the 1960s, when a national expert committee, the Ottosen committee, proposed the creation of university colleges through upgrading of professional schools (Aamodt, 1995). Over the years the higher education system changed its structure several times following two waves of institutional mergers, one in the 1990s and a more recent one that started in 2015, as well as institutional upgrading of some university colleges to universities. Today it consists of eight public universities, eight public university colleges and five public specialized scientific colleges. ${ }^{1}$ In addition Norway has 23 private, mainly small higher education institutions that receive government support. Student numbers in Norway saw a steady increase over the last years leading up to a total of 273,227 students in 2016. ${ }^{2}$ Public higher education institutions are still state-owned and regarded as subordinate institutions to the Ministry of Education and Research. Consequently, they are in general subject to same rules as all public agencies within the civil service (Dimmen \& Kyvik, 1998).

The Norwegian higher education system relies mainly on public funding as its most important source of income, and block funding from the Ministry is still the largest funding source even though external funding increased more than basic funding in recent years (Wendt, Söder, \& Leppälahti, 2015). ${ }^{3}$ Tuition fees of any kind, both for domestic and foreign students, are regarded as a political taboo, even after several other Nordic states introduced tuition fees for non-EU students (Christensen, Gornitzka, \& Maassen, 2014). Consequently Norway has a $4 \%$ share of private expenditure on higher education, which is one of the lowest in the OECD context. ${ }^{4}$

While the Nordic region as a whole is among the world leaders in the level of total spending on research and development (R\&D) in relation to its GDP, Norway is somewhat of an exception with a R\&D/GDP ratio of 1.95 in 2015, which is considerably lower than the ratios of Denmark, Finland and Sweden. ${ }^{5}$ However, one has to keep in mind that Norway has an exceptionally high GDP due to its income from natural resources. Additionally, Norway is still above the OECD average concerning its level of spending on higher education R\&D and the strong growth in R\&D spending in the Nordic region especially between 2010 and 2013 is also reflected in Norway, however, again in a somewhat limited way (Wendt, Söder, \& Leppälahti, 2015).

The Australian higher education system comprises currently 40 full universities. Out of these, the vast majority (37) can be labeled public universities. The Australian system of higher education classifies as a 'unitary system', meaning that the bulk of higher education activity is carried out in one type of institution - the Australian university. ${ }^{6}$ The unitary character of the Australian higher education system

\footnotetext{
${ }^{1}$ See https://www.regjeringen.no/en/dep/kd/organisation/kunnskapsdepartementets-etater-ogvirksomheter/Subordinate-agencies-2/state-run-universities-and-university-co/id434505/ (02.08.2017)

${ }^{2}$ See: http://www.ssb.no/en/utdanning/statistikker/utuvh_(02.08.2017)

${ }^{3}$ However, the trend was less pronounced in Norway compared to the other Nordic countries.

${ }^{4}$ See: http://www.oecdilibrary.org/docserver/download/9614011ec066.pdf?expires=1455538099\&id=id\&accname=oid037306\&check sum=DA3387995C42149FD25715C561CFA80C (02.08.2017)

${ }^{5}$ See: https://data.oecd.org/rd/gross-domestic-spending-on-r-d.htm (02.08.2017).

${ }^{6}$ In the current Australian context, the designation 'higher education' is generally reserved for universities and their activities, whereas 'tertiary education' is used to refer to all providers of post-secondary education,
} 
is the result of the sweeping higher education policy reforms conducted by Australian federal government in the late 1980s (see Croucher, Marginson, Norton, \& Wells 2013; Meek 1991). As a result of these reforms, the two major types of higher education providers existing at the time - all 19 universities and 46 Colleges of Advanced Education (CAE) - were integrated in a single system generally comprising only universities.

The creation of a unitary system of higher education heralded both a rapid increase in the number of Australian universities as well as a substantial increase in the number of students attending higher education institutions. In 1987, the year prior to the creation of a unitary system, there were 19 universities; already four years later there were 31 of them. Over the same period, enrolment at higher education institutions in Australia rose from 393,000 to around 534,000. ${ }^{7}$ In 2015, there were around 1.2 million students enrolled at Australian higher education institutions. ${ }^{8} \mathrm{~A}$ substantial proportion of these (23\%) were international students paying significantly higher fees than their domestic counterparts.

The tuition fees paid by international students have become a major stream of Australian universities' revenue, now making up around 25 per cent of university revenue on average. These funds have compensated to some extent for the increasing shortfall in public funding to cover universities' operating costs. In 1987, just prior to the policy reforms referred to above, 85 per cent of the overall revenue of Australian universities came, in one form or another, from the Australian government (Marginson 1997, 68). By 2013, this figure had dropped to just below 45 per cent (Department of Education 2014, 3). Despite this overall decrease in the level of public funding, Australian Universities continue to be highly dependent on government for the funding of their research. This is mainly due to the fact there is not a strong tradition in Australia of university-industry collaboration, with relatively little private money supporting university-based research activities (see OECD 2015, 65). This may have to do with the fact that Australian industry, just as its Norwegian counterpart, has a strong focus on primary resources, most of all mining, which is an industry "in which R\&D is traditionally low relative to the level of business turnover" (Larkins 2011, 257). Overall expenditure for R\&D (as share of GDP) in Australia sat at $2.11 \%$ in 2013 , which is below the OECD country average for this year $(2.37 \%){ }^{9}$

\section{Agentification and higher education policy re-configurations in Norway}

Norwegian higher education has traditionally been characterized as a rather slow reformer, partly due to tendencies towards localism and incrementalism that made larger and more radical reforms difficult (Kogan, Henkel, Bauer, \& Bleiklie, 2006). At the same time, the relationship between the state and Norwegian higher education has been characterized by consensus and dialogue (Stensaker, 2006). However, following the extensive reforms of the 1990s and early 2000s there are increasing signs that the institutional framework of Norwegian higher education is becoming more open to reforms and transformation (Bleiklie, 2009).

including not only universities but also the many Technical and Further Education (TAFE) institutes and Registered Training Organisations (RTOs).

${ }^{7}$ See: https://www.education.gov.au/selected-higher-education-statistics-time-series-data (02.08.2017).

${ }^{8}$ See: https://www.education.gov.au/selected-higher-education-statistics-2015-student-data (02.08.2017).

${ }^{9}$ See: https://data.oecd.org/rd/gross-domestic-spending-on-r-d.htm (02.08.2017). 
Most reforms in Norwegian higher education have been based on reports by national expert commissions. These commissions often fulfill two functions. On the one hand, they provide a specific expertise, which can be related to the idea of using strategic intelligence to review policy-making arrangements. On the other hand, these expert commissions are also an expression of the consensual policy-making style in Norway. One of the early examples of such an expert commission was the already mentioned Ottosen commission in the 1960s whose report led to the creation of university colleges as new types of higher education institutions (Aamodt, 1995). These new institutions were created through upgrading regional vocational schools, thus the regional governments were strongly involved in governing these institutions, leading to a growing number of actors in Norwegian higher education.

Between 1975 and 1987 nearly all expansion in higher education took place in the new college sector while the number of university students and the level of invested resources remained rather stable (Aamodt, 1995). This situation sparked an intense higher education policy debate in the spring of 1987, especially concerning the role of universities and the lack of quality and ambition in Norwegian higher education. As a reaction to this debate the government appointed a new expert commission, the Hernes commission, to review the development of Norwegian higher education. The commission delivered its report in 1988 and most of the recommendations have been followed up by policy-makers (Aamodt, 1990). The Hernes report is often described as the central starting point for Norwegian higher education reforms in the following decades (Aamodt, 1990; Stensaker, 2006), also due to its focus on quality of higher education as a key challenge, which also underpinned the rhetoric of several reform initiatives in the 2000s and today.

The report of the Hernes commission argued for several reforms in higher education. First, the committee argued that higher education has to recruit a larger proportion of students from more diverse backgrounds to counter decreasing birthrates (Aamodt, 1990). Moreover, the Hernes commission wanted to improve the cooperation between higher education institutions to facilitate the division of labor in the system, and stop further decentralization of higher education by preventing the creation of new institutions. Furthermore, they called for a minimum size of institutions and subsequent mergers of very small regional colleges. In the actual merger processes taken place in the early 1990s the number of university colleges was reduced from 98 to 26 (Aamodt, 1990).

With regard to the governance of higher education the reforms initiated on the basis of the Hernes report focused on more decentralization of authority and a decreasing emphasis on regulations and control through the Ministry especially concerning budgetary systems and administrative planning (Aamodt, 1990). Outcomes of this were the creation of university boards to replace senates as the highest institutional bodies in 1989 as well as a greater focus on academic leadership on both the institutional and departmental level. On the national level, the Hernes commission proposed an intermediary agency in the form of a national board for higher education and research to be created as a buffer between the Ministry and the sector. However, this proposal was one of the few that was not accepted by the parliament (Aamodt, 1990).

Historically Norwegian universities were regulated individually by separate laws through which the government set the general framework of the activities of each institution. This situation changed in the aftermath of the Hernes report with the Higher Education Act of 1995, which for the first time brought all public higher education institutions under the same law and thus can be seen as a prerequisite for a more concerted form of policy coordination (Bleiklie, 2009). Prior to this unification 
of the regulatory framework many decisions on detailed matters, such as establishment of new professorial positions, had to be taken by the national parliament. Thus, the Higher Education Act created a relation between institutions and the Ministry that put stronger emphasis on academic and administrative leadership and gave more autonomy to universities (Dimmen \& Kyvik, 1998).

Following the establishment of the Higher Education Act, in the late 1990s and early 2000s the relationship between the state and higher education institutions underwent a second major shift from emphasizing rules in higher education governance towards relying on management by objectives and outcomes (Larsen \& Gornitzka, 1995), including a shift from ex ante to ex post control. The new focus on result-oriented planning was accompanied by the introduction of a new budget system with output indicator components as well as quality assessments (Stensaker, 1998). However, the delegation of authority from the Ministry to higher education institutions was only implemented in a limited way and the government remained the strongest actor in higher education as e.g. the introduction of new study programs still had to be approved by the government (Dimmen \& Kyvik, 1998). So even after the reforms in governance that have been inspired by the Hernes report, Norway was still characterized by a strong state dominance concerning funding, regulation and admittance in higher education as well as the absence of any significant intermediary agency, besides the research council that focused only on distributing research funds (Stensaker, 2006).

This stability was not necessarily a sign of the state's desire to keep in control of higher education. To the contrary, an attempt to change the legal status of higher education institutions from special civil service institutions to public enterprises failed in the early 2000s. This failure was due to the resistance from within the higher education sector, which saw the proposal by the government as a dangerous step towards marketization of higher education (Bleiklie, 2009). This refusal of a new organizational form of universities is yet another indicator for the stability of policy and governance arrangements in Norwegian higher education and for the incremental nature that characterizes many change processes in the sector.

During the course of the reforms described above, the Ministry responsible for higher education also underwent several structural changes. In 1982 the responsibilities for higher education and research were transferred to a new Ministry of Cultural and Scientific Affairs. ${ }^{10}$ Following some additional reorganizations the Ministry was renamed in 1991 to the Ministry of Education, Research and Church Affairs including not only higher but also secondary and primary education, and from 2006 onward, also pre-school education. Thus, Norway used a unifying approach of forming an overarching Ministry for key matters related to (higher) education as a way to increase the potential for policy coordination. This can be described as a softer version of the 'superministry' approach since the functions that were united in the new larger Ministry were still close to the core policy area of higher education and, for example, did not include parts of the Ministries of Labor or Business. However, while the Ministry as a whole steadily became more encompassing, it kept an internal division with separate departments for different levels of education as well as research. ${ }^{11}$

After granting the higher education institutions more autonomy and reorganizing the Ministry the central development in Norwegian higher education governance in the late 1990s and 2000s is the emergence of a number of intermediary agencies and institutions that are linked to the Ministry and

\footnotetext{
${ }^{10}$ See: https://www.regjeringen.no/en/dep/kd/areas-of-responsibilities/history/id614/ (02.08.2017)

${ }^{11}$ See: https://www.regjeringen.no/en/dep/kd/organisation/Departments/id613/ (02.08.2017)
} 
its respective departments. These include, amongst others, the Norwegian Centre for International Cooperation in Higher Education (SIU), the Research Council of Norway, and the quality assurance agency Nasjonalt organ for kvalitet $i$ utdanningen (NOKUT). ${ }^{12}$

Many of the agencies active in higher education policy were created in the aftermath of the structural changes of the 1990s and their number increased significantly during the last twenty years. While the merger between the Council of Norwegian Colleges and the Council of Norwegian Universities in 1997 to the Council of Norwegian Universities and Colleges (Bleiklie, 2009) led to a decrease of stakeholder organization and more coordination between the different types of higher education institutions, the following years saw the creation of several new bodies that became active in higher education policymaking. In 1998 the government created the Network Norway, an advisory body for higher education under the Ministry that had the aim to support student mobility and institutional profiling in higher education (Bleiklie, 2009). This body was transformed in 2003 in the aftermath of the so called "quality reform" into NOKUT, the Norwegian quality assurance agency. NOKUT is an intermediary and independent agency under the Ministry of Education and Research, which is responsible for accreditation of higher education institutions and study programs in Norway as well as the assessment of applications of Norwegian university colleges to be upgraded to full universities, a responsibility that became part of their mandate after their establishment. ${ }^{13}$ NOKUT has strong formal powers, due to its responsibility to decide about institutional upgrading as well as the accreditation of study programs. However, due to the incremental and consensual policy-making environment NOKUT's formal power can be seen to be somewhat limited through the informal environment. Therefore, it can be best described in Capano and Turri's (2016) classification as an additional agency.

In a second process to create more coordination among the intermediary bodies in higher education, the different research councils that existed in Norway since the late 1940s and which operated separately based on a disciplinary structure, were united in 1993 into one national body, the Research Council of Norway (Arnold, Kuhlmann, \& van der Meulen, 2001). Instead of preserving the internal division along disciplinary lines, the programs of the new research council were supposed to break up disciplinary structures (Bleiklie, 2009), and from 2003 onwards the work of the research council was structured along the division of basic research, applied research and innovation. Thus, Norway not only delegated responsibilities from the Ministry to the agencies in an attempt to increase coordination, but further increased the level of coordination through mergers between agencies. Given its main role as a distributor of public research funding the Research Council of Norway only has a limited amount of formal power and can therefore be described as an instrumental agency that the government mainly uses to administer and implement research programs.

In the frame of the encompassing higher education reforms of the early 2000s Norway also undertook shifts in its funding regime for higher education. From 2003 onwards the country moved away from a controlled and rule-based funding system to one which is market-oriented and incentive based (Frølich, Kalpazidou Schmidt, \& Rosa, 2010). In the new system the two major funding sources for higher education are block grants, which include performance-based components, allocated by the Ministry of Education and Research, and competitive research funding which is administered by the

\footnotetext{
12 It should be pointed out that formally all universities and university colleges are also subordinate institutions to the ministry. See: https://www.regjeringen.no/en/dep/kd/organisation/kunnskapsdepartementets-etaterog-virksomheter/id2344548/ (02.08.2017)

${ }^{13}$ See: http://www.nokut.no/en/About-NOKUT/ (02.08.2017)
} 
Research Council of Norway (Bleiklie, 2009). In this, the development of higher education funding in Norway is comparable to most other European countries as it includes more lump sum funding, increased autonomy and governance through results-based funding (Wendt, Söder \& Leppälahti, 2015). While these developments give the higher education institutions more room to maneuver they do not question the generally important role of the state for higher education funding, as even though several attempts have been made to strengthen the link between research and business interest, public and private research funding and activities largely remain separated (Bleiklie, 2009). Thus, one can observe an increasing use of incentive-based funding using performance indicators both with regard to teaching and research combined with control mechanisms through government agencies such as the quality assurance agency NOKUT.

In total, the reforms that took place in the Norwegian higher education sector in recent years have had mixed results. On the one hand, they did lead to an increased number of actors being involved in the governance of the sector, changes in the number of higher education institutions, more influence from international policy agreements, such as the Bologna Process, and the introduction and reorganization of intermediary agencies, such as NOKUT and the Research Council of Norway. On the other hand, the changes in type and number of actors involved in governing the sector happened within traditional state structures, leading to a preservation of a traditional hierarchical governance arrangement instead of a move towards a market or network-based type (Bleiklie, 2009). Therefore the main shift can be seen in the growing role of intermediary agencies in the governance of higher education. However, the power that these agencies have is still somewhat limited also due to the incremental and consensual policy-making tradition, which puts limits on the informal powers of agencies.

Overall, one can say that there has been a remarkable stability in Norway regarding the institutional matrix that is active in regulating and coordinating higher education policy and that the control of the state over higher education and research is in general not weakened. Higher education institutions have been and are still regarded as integral parts of the civil service and are subordinate bodies to the responsible Ministry. This relates to a neo-Weberian approach to public sector reforms and highlights the overall slow speed of shifts in Norwegian higher education governance, which can further be characterized to be based on low levels of conflicts and long-term policy developments rather than quick and radical changes (Bleiklie, 2009). This is also reflective of reforms in other parts of the public sector that have been undertaken during the 1990s and 2000s (see Bezes, Fimreite, Lidec \& Lægreid, 2013; Lægreid, Rolland, Roness, \& Ågotnes, 2010).

\section{Agentification and higher education policy re-configurations in Australia}

As already indicated, Australia has been in the vanguard internationally in implementing higher education reforms along principles that strongly resonate with core NPM ideas and agendas (see, for example, Hicks, 2012; Marginson, 1997). Furthermore, Australia arguably went further and, to this day, has been more persistent than most other governments in in its pursuit of NPM-style policies (see Lewis, 2015; Woelert \& Yates, 2015). The Dawkins higher education policy reforms - named after the Labor Education minister John Dawkins and taking place between 1987 and 1989 - are generally considered the watershed point in this regard, setting Australian higher education on a policy trajectory radically different compared to times prior. 
The Dawkins reforms entailed fundamental changes to university funding and governance, as well as enduringly transforming higher education policy coordination at the national level. In terms of funding, the reforms reintroduced tuition fees for domestic students, and introduced a comprehensive governmental system providing loans to students to cover their tuition costs. The reforms further established a performance-based funding system allocating funds on the basis of "a range of output, quality and performance measures" (Dawkins 1988, 85). To this day, however, performance-based funding in Australia mainly and comprehensively targets university-based research, and less so teaching and other activities.

In terms of governance, the Dawkins reforms started a trend that resulted in enhancing university autonomy in terms of internal managerial matters and affairs (see Marginson \& Considine 2000). Overt government regulation of specific university-internal organizational procedures and processes in domains such as budgeting and human resources was reduced, at least ostensibly. This said, this increase in managerial autonomy has been accompanied by a proliferation of formal evaluation mechanisms and increased reporting requirements that, some have argued, ultimately means more governmental control of and over universities, not less (Marginson, 1997; Vidovich, 2002; and Woelert, 2015; see also Capano, 2015; and Christensen, 2011).

Finally, the Dawkins reforms radically remodeled national higher education policy coordination - and this to such an extent that some of the immediate effects are still shaping policy processes nearly 30 years on. In what follows the focus will be on describing and analyzing two interrelated developments that are of particular interest given the research question addressed. First, with the Dawkins reforms, the federal government, and the federal Ministry responsible for education more narrowly, established itself as the major policy actor for higher education - despite having at the time formally no legislative power over Australian higher education institutions (Meek, 1991). Second, the reforms radically and enduringly reshaped the forms and powers of intermediary agencies in the higher education policy space.

Traditionally and formally, most of legislative responsibility for higher education and its institutions lies with the six Australian states rather than with the federal government. This said, since the 1950s the federal government has taken an increasingly prominent role in developing and enacting higher education policy in Australia. This increase parallels and indeed reflects the federal government's increasing involvement in university funding since that period, with the federal government having provided the bulk of public funding to higher education institutions in Australia since the mid-1970s (Meek, 1991, 465; see also Vidovich, 2002, 400). The state governments continue to play, formally at least, a central role in accrediting new universities. They also have formal representation on university councils, and have also been represented over the years in various national agencies, such as the quality assurance body 'Australian Universities Quality Agency' (AUQA, see below).

The Dawkins reforms significantly added to the momentum towards federal government assuming major responsibility for and control over higher education policy development and implementation. Not only did the disestablishment of the state-controlled and funded CAEs mean that state governments ceded most of the direct policy control they hitherto had over the higher education sector, but the reforms also arguably weakened the influence the university sector could exert on the development of higher education policy. One key factor in this regard was the demise of the Commonwealth Tertiary Education Commission (CTEC), which Minister Dawkins chose to abolish in 1987. 
CTEC was an intermediary agency with the status of an independent statutory authority that provided expert policy advice to federal government. ${ }^{14}$ CTEC can be regarded a 'superagency' in the sense that it had policy responsibility for all major higher education functions (research and teaching), while also playing a central role in advising on funding levels for individual institutions (see Harman, 1984). While it has been argued that CTEC did not possess the same level of autonomy as its precursors and also came under the increasing control of federal government over the years (Harman, 1984), it nevertheless remained overall relatively autonomous in its various policy functions. This was an intended feature of its design as a 'buffering' body that was supposed to shield higher education institutions from overt political interference by federal government (Marshall, 1990; Harman, 1984). This enabled an impartial, well-informed and consultative form of higher education policy making. Using the typology of agencies referred to earlier, CTEC may best be classified as a hybrid between a dominant and an additional agency. CTEC can be deemed a dominant agency in that it was formally established as an intermediary body and over the time of its existence was the major policy actor in the field as well as the public institution in which most higher education policy expertise was concentrated. At the same time, repeated instances of governmental intervention into higher education policy affairs also means that at times at least CTEC's actual policy role was more additional than dominant.

In the late 1980s - a period of economic downturn in Australia - powerful buffering bodies, such as CTEC, were increasingly seen by the Australian federal government as an obstacle to a coherent and effective coordination of policy making and implementation (Marshall, 1990, 162-3). Particularly contentious for government was that CTEC's relative autonomy and close engagement with and sensitivity towards higher education institutions also meant that it was able to act as a "quasi-pressure group with respect to government" (Meek, 2002, 57) - potentially to the point where it was 'captured', especially by the well-established universities, to make policy suggestions on their behalf (see on this point also Blackmuir, 2007, 34-35).

The abolishment of CTEC served to relocate higher education policy functions to a newly-created, comprehensive Department of Employment, Education and Training (DEET) that was under a direct form of ministerial control (Marginson 1997, 67). This, it has been frequently noted, also facilitated a more direct ministerial control of the activities of universities (Marshall, 1990; Meek, 2002). This shift from CTEC to the DEET clearly signaled an incisive shift from a model of policy coordination that was centered on a relatively powerful agency to a 'superministry' approach entailing strong leadership at the ministerial level.

The strong emphasis on ministerial leadership has been preserved to this day, and is reflected in some continuing idiosyncrasies that distinguish Australia from other liberal democracies (see below). Yet this emphasis did not always entail the persistence of the 'superministry' approach. Since the Dawkins reforms period, there has been remarkably little continuity on the level of government when it comes to the organization of departmental policy responsibility for higher education. For example, policy responsibility for two core functions of higher education - teaching and research - has periodically been split up between various departments (e.g., 2007-2011), only to be subsequently brought

\footnotetext{
${ }^{14}$ CTEC was established in 1977 by the Liberal Party government, through merging the previously existing Australian Universities Commission (AUC) and some governmental agencies overseeing activities in the tertiarty education sector (Harman 1984; Marshall 1990). AUC was a coordinating agency established in 1959 and which was modelled - like so many other higher education governing bodies, policies and processes in Australia up until the present - after an already existing British counterpart.
} 
together under the umbrella of a new 'superministry' (2011-2013), after which it was again briefly separated (2013) and recombined (2013-16). Furthermore, at times, higher education was part of policy portfolio that focused specifically on all matters concerning education and research, housed in one standalone department of education (e.g., 2001-2007; 2013-16). At other periods, however, responsibility for key aspects of higher education policy was with departments also responsible for policy areas such as employment and workplace relations (2007-2013) or, in the case of research policy, industry (e.g., 2007-2011, 2013).

Even more strikingly has been the tendency of federal governments over recent decades to ever more frequently re-label and/or restructure those departments with policy responsibility for the higher education sector. In the last ten years alone (2006-2016) there have been seven of such changes, resulting in the creation of departments the names of which have an almost Kafkaesque dimension. ${ }^{15}$ Key personnel responsible for higher education at the departmental level in Australia changed even more frequently than departments.

Since the Dawkins reforms, Australian governments have not made any serious attempt to reestablish an intermediary agency enjoying the sort of policy autonomy and capacity that CTEC had. And yet, it would be too simple to say that developments since the Dawkins reforms mark the definite departure from agentification in Australian higher education policy coordination. Already the immediate aftermath of these reforms saw developments that resulted in various agencies being tasked not only with advising on policies, but also with monitoring and coordinating core activities of universities. As we will see, however, all these agencies tend to be closely controlled by government and thus can be classified as belonging to the instrumental type of agency.

With respect to agentification in the domain of research policy, one key development was the establishment of the Australian Research Council (ARC) in 1988. The ARC was established as a governmental body with council functions, to advise on research policy matters, yet it also happened to quickly take on broader responsibilities for implementing research strategy and competitive funding initiatives (Larkins 2011, 30). In 2001, the ARC was turned into a statutory authority that was formally independent, and also assumed "full administrative responsibility for the assessment of grant applications" in the majority of academic fields. ${ }^{16}$ Yet despite this apparent independence, the Australian federal government and the responsible minister in particular are legally able to exercise considerable control over ARC's strategy and processes, to a level that goes beyond what is common in many other liberal democracies (see Woelert \& Yates, 2015, 179-180). For example, the Australian Research Council Act 2001 reserves the ultimate right for appointing the ARC's CEO to the responsible minster of the government (ARC, 2001, 19). The minister also can exert a direct influence on the actual allocation of ARC research grants, as all individual research grants decisions require approval by the responsible minister. In particular, the minister has the right to veto funding decisions already made by the ARC; and there are known instances where this right has been exercised (Haigh, 2006). Finally, and in consultation with stakeholders from industry and government, the Australian government also

\footnotetext{
${ }^{15}$ For example, in 2013 such departments included cumbersome creations such as the Department of Industry, Innovation, Climate Change, Science, Research and Tertiary Education.

${ }^{16}$ See: http://www.arc.gov.au/history-arc (02.08.2017).

Exluded was all medical or health science research with a clinical orientation. Responsbility for research garnt allocations for these forms of research continues to be with the National Health and Medical Research Council (NHMRC), which was formed already in 1937 and gained the status of an independent statutory agency in 1992 (Larkins 2011, 168)
} 
sets the national research priority areas that receive preferential treatment in ARC grant rounds. Being primarily charged with the administrative tasks of policy implementation and having little control over broader policy agendas and directions, the ARC unambiguously classifies as an instrumental agency.

With respect to teaching, the major development since the Dawkins reforms has been the successive establishment of a range of agencies with responsibility for quality assurance (QA) policies and processes (Vidovich, 2002, 2012). The first of such agencies was the Committee for Quality Assurance in Higher Education (CQAHE). The CQHAE was established in 1993 to administer, implement and refine QA policies initially conceived of by the responsible federal ministry. It was ultimately succeeded by the Australian University Quality Agency (AUQA), which was established in 2000. The AUQA was in turn replaced by Tertiary Education Quality and Standards Agency (TEQSA) established in 2011. It has been noted that, over the time of its evolution, QA bodies and their policies have become more closely controlled by government, with the major QA bodies ceding their initial 'buffering' function (Vidovich, 2000; Vidovich \& Slee, 2001). For example, with the shift from CQAHE to AUQA the government came to dominate the board of the major quality assurance body, having twice as many representatives as the higher education sector (Vidovich \& Slee, 2001, 439-440). Further and more recent trends include an increasing concern with standards, emphasis on external rather than internal forms of accountability, audits of higher education providers, as well as a transition from qualitative to quantitative measures (Vidovich, 2012). TEQSA and its precursors have been narrowly concerned with the technical and administrative details of policy implementation. This suggests their primary classification as instrumental agencies. Beyond that, impasses in the government's recent attempts of policy reform also may warrant, in the instance of TEQSA at least, a secondary classification as administrative agency.

Overall, in the Australian case the more recent proliferation of agencies thus does not signal a departure from, but rather an intensification of a state-centric approach to higher education policy coordination and governance more broadly - where control may be more remote but actual control mechanisms are both more comprehensive and intrusive. The key in this regard has been a shift from one comprehensive buffering agency (CTEC) that possessed a certain degree of autonomy to a configuration that has a powerful Ministry at the center and which also includes several dependent agencies. These agencies are mainly charged with the administrative tasks of policy implementation, and due to the configuration of the field, are incapable of effectively fulfilling any genuine buffering function.

\section{Conclusion: Agentification and higher education policy dynamics in the two countries}

In this chapter we have compared how two countries, Norway and Australia, have reconfigured their policy-making processes in higher education over the last three decades under particular consideration of the role of agentification. By analyzing in detail the development of government agencies in two countries over a longer period of time and through embedding this development in the wider institutional matrix of higher education policy coordination, the analysis presented in this chapter goes beyond the few existing comparative examinations (e.g. Capano \& Turri, 2016). Of the two analyzed countries, one - Norway - is commonly characterized as both state-centric as well as a latecomer when it comes to reforming its higher education policy arrangements. The other country - Australia - is regarded as protagonist of NPM reforms internationally, which on some terms at least would signal a departure from state-centric approaches to policy coordination. 
The comparison of the two cases has yielded several striking convergences in more recent approaches to higher education policy coordination. In both countries, over the last two decades, there has been a proliferation of agencies involved in higher education policy processes. In both countries, these agencies are charged with policy development or implementation functions, with a common thematic focus on competitive arrangements for research and quality assurance systems for teaching activities. Both countries also have, at various stages, adopted some form of a 'superministry' approach to higher education policy coordination, at times running parallel to attempts to increase agentification. At a first glance this seems to support that agentification is part of a global script leading to homogenizing policy dynamics across national higher education settings.

However, a more scrutinizing perspective has revealed important differences between the two countries. While agentification can be observed in Norway, both central agencies, NOKUT and the Norwegian Research Council, have gained only limited power, and the state still has a high level of direct control over higher education policy matters. All this may reflect what has been dubbed a 'neoWeberian' approach to public sector reforms (Bleiklie 2009), which can further be characterized to be based on low levels of conflict and long-term policy developments rather than quick and radical changes. By comparison, scrutiny of the Australian case suggests that over the last two decades, agentification has actually extended governmental control - and ministerial control more specifically - of higher education policy processes. This was most apparent in the fact that the major agencies more recently established in Australia have only very limited autonomy and as such do not have a 'buffering' capacity that would compare to that granted to CTEC, the major intermediary agency existing prior to the 1980 s reforms.

Moreover, the analyses reveal significant differences in the institutional dynamics associated with the above developments. In Norway, institutional reforms developments can be described as slow and incremental, increasing in intensity only comparatively late, in the early 2000s. Most of these reforms were driven by reports from expert commissions that made policy development less of a partisan issue and more anchored in expertise and consensual policy-making. This overall slow development is also reflected in the remarkable stability regarding the institutional matrix that is active in coordinating higher education policy at the governmental level. In Australia, there was a sweeping set of radical higher education policy reforms already in the late 1980s, which set the broader frame for future policy directions and developments over the next few decades. Yet over the same period developments in Australia reveal considerable volatility and hence instability in terms of the institutional bodies responsible for higher education policy processes. This was most striking with regard to numerous instances of a relabeling and also restructuring at the level of ministries (and to lesser degree at the level of agencies also) that have responsibility for higher education policy matters.

Relating the results of our analysis to the ideas of global scripts and potential national filters (Gornitzka \& Maassen, 2014), it becomes clear that there remain significant discrepancies despite some broader convergence tendencies. One discrepancy concerns the speed in which reforms were implemented, with major differences in the stability of institutional bodies also being apparent. Our discussion also suggests that there are important differences in the governance effects of agentification in each country. While in Norway agentification has not yet led to a significant decrease in the steering control government exercises over higher education policy affairs, in Australia agentification apparently has increased rather than decreased such control. All this rather supports the idea of the existence of national filters adapting global reform trends to what is seen as legitimate and appropriate in a given 
national context and to a certain extent contradicts the strict convergence assumption that is inherent in the idea of global scripts.

The research presented here could be taken forward in a number of ways. First, as the results call into question the strict convergence assumption of the global scripts argument, a potential next study could strengthen the empirical focus and try to find explanatory variables that allow clustering a broader set of countries according to the way they have addressed the common challenges of agentification and coordination of higher education policy. Second, a broader empirical study potentially enables refining the two typologies of agencies and of institutional options for policy coordination used here, and may help identify any additional forms and options that have not yet been considered. Finally, as this contribution focused on the arrangements on the national level, it would also be a relevant next step to analyze their potential impact on the internal governance and organization of individual universities. 


\section{Literature}

Aamodt, P. O. (1990). A New Deal for Norwegian Higher Education? European Journal of Education, 25(2), 171-185. doi:10.2307/1503087

Aamodt, P. O. (1995). Floods, bottlenecks and backwaters: an analysis of expansion in higher education in Norway. Higher Education, 30(1), 63-80. doi:10.1007/bf01384053

Altbach, P. G., Reisberg, L., \& Rumbley, L. E. (2009). Trends in Global Higher Education: Tracking an Academic Revolution. A Report Prepared for the UNESCO 2009 World Conference on Higher Education. Paris: UNESCO.

Andres, L., \& Pechar, H. (2013). Participation Patterns in Higher Education: a comparative welfare and production régime perspective. European Journal of Education, 48(2), 247-261. doi:10.1111/ejed.12028

Arnold, E., Kuhlmann, S., \& van der Meulen, B. (2001). A Singular Council. Evaluation of the Research Council of Norway. Retrieved from: https://www.regjeringen.no/globalassets/upload/kd/vedlegg/forskning/rapporter/2001-rcneval/2001-evaluation-of-the-research-council-of-norway.pdf?id=2248198 (28.11.2016)

Bezes, P., Fimreite, A. L., Lidec, P. L., \& Lægreid, P. (2013). Understanding Organizational Reforms in the Modern State: Specialization and Integration in Norway and France. Governance, 26(1), 147-175. doi:10.1111/j.1468-0491.2012.01608.x

Blackmuir, D. (2007). The public regulation of higher education qualities: Rationale, processes, and outcomes. In D. F. Westerheijden, B. Stensaker, \& M. Joao Rosa (Eds.), Quality Assurance in Higher Education: Trends in Regulation, Translation and Transformation (pp. 15-45). Dordrecht: Springer.

Bleiklie, I. (2009). Norway: From Tortoise to Eager Beaver? In C. Paradeise, E. Reale, I. Bleiklie, \& E. Ferlie (Eds.), University Governance (Vol. 25, pp. 127-152). Dordrecht: Springer.

Bleiklie, I., \& Michelsen, S. (2013). Comparing HE policies in Europe. Higher Education, 65(1), 113133. doi:10.1007/s10734-012-9584-6

de Boer, H. F. (1992). Walking tightropes in higher education. Higher Education Policy, 5(S3), 36-40. http://doi.org/10.1057/hep.1992.47

Braun, D. (2008). Organising the political coordination of knowledge and innovation policies. Science and Public Policy, 35(4), 227-239. doi:10.3152/030234208×287056

Capano, G. (2015). Federal Strategies for Changing the Governance of Higher Education: Australia , Canada and Germany Compared. In G. Capano, M. Howlett, \& M. Ramesh (Eds.), Varieties of Governance: Dynamics, Strategies, Capacities (pp. 103-130). London: Palgrave Macmillan.

Capano, G., \& Turri, M. (2016). Same Governance Template but Different Agencies. Higher Education Policy. Online first, http://doi.org/10.1057/s41307-016-0018-4

Christensen, T. (2011). University governance reforms: potential problems of more autonomy? Higher Education, 62(4), 503-517.

Christensen, T., Gornitzka, A., \& Maassen, P. (2014). Global Pressures and National Cultures. A Nordic University Template? In P. Mattei (Ed.), University Adaptation in Difficult Economic Times (pp. 30-51). Oxford: Oxford University Press.

Christensen, T., \& Lægreid, P. (Eds.) (2006). Autonomy and Regulation: Coping with Agencies in the Modern State. Cheltenham, UK: Edward Elgar.

Commonwealth of Australia (2001). Australian Research Council Act 2001. Canberra.

Croucher, G., Marginson, S., Norton, A., \& Wells, J. (2013). The Dawkins Revolution: 25 Years on. Carlton, Vic.: Melbourne University Press.

Dawkins, J. (1988). Higher Education: A Policy Statement. Canberra: AGPS.

Dimmen, A., \& Kyvik, S. (1998). Recent changes in the governance of higher education institutions in Norway. Higher Education Policy, 11(2-1), 217-228. doi:10.1057/palgrave.hep.8380105

Frølich, N., Kalpazidou Schmidt, E., \& Rosa, M. J. (2010). Funding systems for higher education and their impacts on institutional strategies and academia: A comparative perspective. 
International Journal of Educational Management, 24(1), 7-21.

doi:10.1108/09513541011013015

Gerring, J. (2007). Case study research. Principles and practices. Cambridge: Cambridge University Press.

Gornitzka, Å., \& Maassen, P. (2014). Dynamics of Convergence and Divergence. Exploring Accounts of Higher Education Policy Change. In P. Mattei (Ed.), University Adaptation in Difficult Economic Times (pp. 13-29). Oxford: Oxford University Press.

Gornitzka, Å., Maassen, P., Olsen, J. P., \& Stensaker, B. (2007). "Europe of Knowledge:" Search for a New Pact. In P. Maassen \& J. P. Olsen (Eds.), University Dynamics and European Integration (Vol. 19, pp. 181-214). Dordrecht: Springer.

Haigh, G. (2006). The Nelson Touch. Research Funding: The New Censorship. The Monthly, (May). Retrieved from http://www.themonthly.com.au/monthly-essays-gideon-haigh-nelson-touchresearch-funding-new-censorship-214 (28.11.2016)

Harman, G. (1984). Australian experience with co-ordinating agencies for tertiary education. Higher Education, 13(5), 501-515. http://doi.org/10.1007/BF00128561

Hicks, D. (2012). Performance-based university research funding systems. Research Policy, 41(2), 251-261. http://doi.org/10.1016/j.respol.2011.09.007

Kogan, M., Henkel, M., Bauer, M., \& Bleiklie, I. (2006). Transforming Higher Education: A Comparative Study (2nd edition). Dordrecht: Springer.

Krücken, G. (2003). Learning the 'New, New Thing': On the role of path dependency in university structures. Higher Education, 46(3), 315-339. doi:10.1023/a:1025344413682

Larkins, F. P. (2011). Australian higher education research policies and performance: 1987-2010. Carlton, Vic.: Melbourne University Press.

Larsen, I. M. \& Gornitzka, Å. (1995). New Management Systems in Norwegian Universities: The Interface between Reform and Institutional Understanding. European Journal of Education, 30(3), 347-361.

Lewis, J. M. (2015). Research Policy as "Carrots and Sticks": Governance Strategies in Australia, the United Kingdom and New Zealand. In G. Capano, M. Howlett, \& M. Ramesh (Eds.), Varieties of Governance. Dynamics, Strategies, Capacities (pp. 131-150). Basingstoke: Palgrave Macmillan.

Lægreid, P., Rolland, V. W., Roness, P. G., \& Ågotnes, J.-E. (2010). The Structural Anatomy of the Norwegian State: Increased Specialization or a Pendulum Shift? In P. Lægreid \& K. Verhoest (Eds.), Governance of Public Sector Organizations: Proliferation, Autonomy and Performance (pp. 21-43). London: Palgrave Macmillan.

Marginson, S. (1997). Steering from a distance: Power relations in Australian higher education. Higher Education, 34(1), 63-80. Retrieved from http://link.springer.com/article/10.1023/A:1003082922199

Marginson, S., \& Considine, M. (2000). The Enterprise University: Power, Governance and Reinvention in Australia. Cambridge: Cambridge University Press.

Marshall, N. (1990). End of an era: The collapse of the "buffer" approach to the governance of Australian tertiary education. Higher Education, 19(2), 147-167. http://doi.org/10.1007/BF00137105

Meek, V. L. (1991). The transformation of Australian higher education from binary to unitary system. Higher Education, 21(4), 461-494. http://doi.org/10.1007/BF00134985

Meek, V. L. (2002). Changing Patterns in Modes of Co-ordination of Higher Education. In J. Enders \& O. Fulton (Eds.), Higher Education in a Globalising World: International Trends and Mutual Observations (pp. 53-71). Dordrecht: Springer.

Meyer, J. W., \& Rowan, B. (1977). Institutionalized Organizations: Formal Structure as Myth and Ceremony. American Journal of Sociology, 83(2), 340-363. http://doi.org/10.1086/226550

Meyer, J. W., Ramirez, F. O., Frank, D. J., \& Schofer, E. (2007). Higher education as an institution. In P. Gumport (Ed.), Sociology of Higher Education: Contributions and Their Contexts (pp. 187221). Baltimore, MD: Johns Hopkins University Press. 
Moran, M. (2003). The British Regulatory State: High Modernism and Hyper-Innovation. Oxford: Oxford University Press.

OECD. (2015). Main Science and Technology Indicators, 2015. Paris: OECD. http://doi.org/http://dx.doi.org/10.1787/msti-v2015-1-en

Pollitt, C. (2005). Ministeries and agencies: Steering, meddling, neglect and dependency. In M. Painter \& J. Pierre (Eds.), Challenges to state policy capacity (pp. 112-136). Basingstoke: Palgrave Macmillan.

Pollitt, C., \& Talbot, C. (2004). Unbundled government: A critical analysis of the global trend to agencies, quangos and contractualisation. London: Routledge.

Pollitt, C., Talbot, C., Caulfield, J., \& Smullen, A. (2004). Agencies: How governments do things through semi-autonomous organizations. Basingstoke: Palgrave Macmillan.

Sanderson, I. (2011). Evidence-based policy or policy-based evidence? Reflections on Scottish experience. Evidence and Policy, 7(1): 59-76. doi: 10.1332/174426411X553007

Stensaker, B. (1998). Culture and Fashion in Reform Implementation: perceptions and adaptation of management reforms in higher education. Journal of Higher Education Policy and Management, 20(2), 129-138. doi:10.1080/1360080980200202

Stensaker, B. (2006). Governmental policy, organisational ideals and institutional adaptation in Norwegian higher education. Studies in Higher Education, 31(1), 43-56. doi:10.1080/03075070500392276

Thelen, K. \& Mahoney, J. (2015). Comparative-historical analysis in contemporary political science. In J. Mahoney \& K. Thelen (eds.), Advances in Comparative-Historical Analysis (pp. 3-36). Cambridge: Cambridge University Press.

Verhoest, K., Peters, B. G., Bouckaert, G., \& Verschuere, B. (2004). The study of organisational autonomy: a conceptual review. Public Administration and Development, 24(2), 101-118. http://doi.org/10.1002/pad.316

Verhoest, K., Thiel, S. van, Bouckaert, G. and Laegreid, P. (2012) Government Agencies: Practices and Lessons from 30 Countries. London: Palgrave.

Vidovich, L. (2002). Quality assurance in Australian higher education: Globalisation and "steering at a distance." Higher Education, 43(3), 391-408.

Vidovich, L. (2012). "Transforming Australia's higher education system": new accountability policies for a global era? In H. G. Schuetze, W. Bruneau, \& G. Grosjean (Eds.), University Governance and Reform: Policy, Fads, and Experience in International Perspective (pp. 241-255). Basingstoke: Palgrave Macmillan.

Vidovich, L., \& Slee, R. (2001). Bringing universities to account? Exploring some global and local policy tensions. Journal of Education Policy, 16(5), 431-453. doi: 10.1080/02680930110071039

Wendt, K., Söder, I., \& Leppälahti, A. (2015). A guide to understanding higher education R\&D statistics in the Nordic countries. Retrieved from:

http://brage.bibsys.no/xmlui/bitstream/handle/11250/282893/NIFUworkingpaper20159.pdf?sequence $=1$ \&isAllowed=y $(28.11 .2016)$

Woelert, P. (2015). The "logic of escalation" in performance measurement: An analysis of the dynamics of a research evaluation system. Policy and Society, 34(1), 75-85. http://doi.org/10.1016/j.polsoc.2015.03.004

Woelert, P., \& Yates, L. (2015). Too little and too much trust: performance measurement in Australian higher education. Critical Studies in Education, 56(2), 175-189. http://doi.org/10.1080/17508487.2014.943776 